\section{4 \\ Enzymic Inactivation of Serum Gonadotrophin}

GONADOTROPHins resemble blood-group specific substances in several respects. Meyer ${ }^{1}$ has classified these compounds together as neutral mucoids; Bussard and Eyquem ${ }^{2}$ claim to have demonstrated a serological relationship between blood-group sub. stances and chorionic gonadotrophin. MeShan and Meyer ${ }^{3}$ have observed inactivation of gonadotrophins by human saliva, whereas Schiff and Akune ${ }^{4}$ found that this material destroyed blood-group $A$ substance. In addition, it has been shown that blood-group sub. stances $^{5,6}$ and serum gonadotrophin ${ }^{7}$ are substrates of the receptor-destroying enzyme produced by Vibrio cholerce and of the similar enzymic component of influenza virus. It would appear, then, that gonadotrophins and blood-group substances have a similar structure and may be inactivated by the same enzymes. This hypothesis was further examined by studying the action on serum gonadotrophin of enzymes which decompose blood-group specific substances.

Morgan $^{8}$ has shown that Clostridium welchii culture filtrates contain enzymes which destroy the serological characteristics of $A, B$ and $O$ substances. The property of destroying $A$ and $B$ substances is lost after heating for $1 \mathrm{hr}$. at $56^{\circ} \mathrm{C}$., but the activity against $O$ substance is retained. A sample of $C l$. welchii (Type B) culture filtrate, partially purified with respect to these enzymes, was kindly supplied by Dr. W. T. J. Morgan, of the Lister Institute. The action of this preparation on serum gonadotrophin has been examined.

Aliquots of the hormone dissolved in phosphate buffer $p H \quad 7.0$ were incubated at $37^{\circ} \mathrm{C}$. for $1 \mathrm{hr}$. with an equal volume of (1) saline (control), (2) 1 in 1,000 solution of enzyme, (3) 1 in 1,000 solution of enzyme which had been held at $56^{\circ} \mathrm{C}$. for $1 \mathrm{hr}$. The activity of the treated hormone was assessed by injecting the equivalent of $50 \mathrm{I.U}$. of the original hormone into each of groups of ten female rats weighing 40-50 gm. The animals were then treated in the usual manner for assay of serum gonadotrophin. Mean ovarian weights obtained during a typical experiment are given in the accompanying table. It is clear that the hormone was inactivated by the heated and unheated enzyme preparations. Since it was found that the preparation possessed no receptor-destroying activity, and testicular hyaluronidase failed to inactivate the hormone, it appears unlikely that the inactivation observed was due to either of the other two recognized mucolytic enzymes produced by $\mathrm{Cl}$. welchii.

Treatment

Serum gonadotrophin, 50 I.U.

Serum gonadotrophin 50 I.U. incubated at $37^{\circ} \mathrm{C}$.

for 1 hour with

1. Saline (control)

. Enzyme preparation

3. Enzyme preparation held at $56^{\circ} \mathrm{C}$. for 1 hour

Uninjected animals

The results indicate that the preparation contained one or more substances which inactivate serum gonadotrophin. That one of these may be identified with the enzyme destroying blood-group $O$ substance seems probable. However, the action of the enzymes which destroy the other blood-group substances cannot be discounted.

The present work, though requiring confirmation with purified enzymes, suggests that gonadotrophins and blood-group substances are similar in that they form common substrates for certain enzymes.

Gordon Craig Research Laboratory,

W. K. WHitTen

Department of Surgery,

University of Sydney, and

Council for Scientific and Industrial Research, Australia.

Sept. 20.

${ }^{1}$ Meyer, K., “Advances in Protein Chemistry", 2, 249 (1945).

2 Bussard, A., and Eyquem, A., Ann. Inst. Pasteur, 78, 1194 (1947). 'McShan, W. H., and Meyer, R. K., J. Biol. Chem., 126, 367 (1938).

'Schiff, F., and Akune, M., Munch. med. Wschr., 78, 657 (1931). - Burnet, F. M., McCrea, J. F., and Anderson, S. G., Nature, 160,
404 (1947).

- Burnet, F. M., Aust. J. Sci., 19, 21.

' Whitten, W. K., Aust. J. Sci. Res. (in the press).

${ }^{9}$ Morgan, W. T. J., Nature, 158, 759 (1946).

\section{A Method for Reducing the Number of Pharmacological Assays}

THe time-concentration curve for the production of a selected drug effect has a well-known shape, the best expression for which approximates to the formula $\left(C-C_{m}\right)\left(t-t_{m}\right)=$ constant. In fact, there is a minimum concentration $C_{m}$ below which the drug will not produce the biological action, and it is certain that in many cases there must be a time $t_{m}$ corresponding to the production of a delayed effect, after the time $t$ needed for the fixation of the drug upon receptors. In some cases $C . t=$ constant gives an approximate fit ; but this merely implies that $C_{m}$ and $t_{m}$ are so small as not to produce a measurable error.

On the other hand, if the effect selected is reversible and detoxication occurs, the time after which complete recovery takes place may be plotted against dosage, and a curve that approximates to a straight line is obtained when the detoxication-rate is supposed to be constant over a sufficiently large range of values. Should the detoxication-rate, according to the mass action law, be proportional to the amount of drug fixed, a logarithmically rising curve would be the rule. The theoretical meaning of $C_{m}$ and $t_{m}$, as well as a complete theory of both the time-concentration curve and the duration-dosage curve, will be given in a subsequent paper.

From the practical point of view, however, it is of interest to note that if both these curves are plotted in the same system of co-ordinates, they intersect in a point which represents the minimum active dose for the effect selected, or at least the dose which is worth considering experimentally, since the threshold $C_{m}$ has only a boundary significance. Furthermore, this point of intersection is to a large extent independent of the statistical distribution of sensitiveness in response to drugs. In fact, in the case of a symmetrical distribution of variation, hyperbolæ 1 and 2 may be assumed to be the limits of the reaction curve $A$; and hyperbolæ 3 and 4 the limits of confidence of the duration curve $B$. Points representing dosages greater than $d_{100}$ lie in the space $a b c d$, and since the probabilities of deviation from the median only differ from each other by the plus or minus sign, the sensitiveness of the effectors is not concerned: the points can be used, therefore, for calculating the reaction curve $A$ by the usual method of least squares. Similarly, points representative of dosages less than $d_{0}$, which must lie in the space $k h j l$, can be used for calculating the 